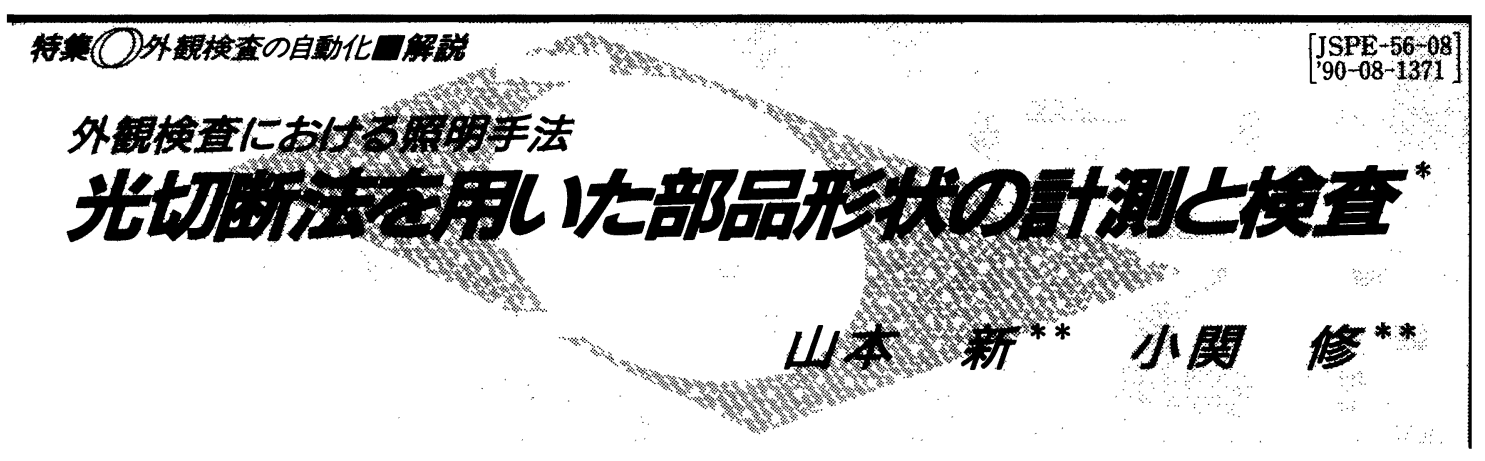

3-D Shape Measurement and Inspection with Structured Light /

Shin YAMAMOTO and Osamu OZEKI

Key words : slit-ray projection, structured light, 3-D vision sensor, shape measurement, solder joint injection

1. はじめに

各産業分野の生産工程では, 検査品質の向上と省人 化の点から検査の自動化への要望が非常に強い. 特 に, この数年は 3 次元形状物体の計測と検査への期待 が急速に高まっている.

検査の自動化には画像処理技術が有効で，2 值画像 処理を用いた検査は広く実用化されているが，3次元 画像の本格的活用はこれからという状況である. 3 次 元画像を用いた計測と検査には, 検査すべき対象物体 の 3 次元情報を得ることが不可欠である. 物体の 3 次 元情報を得るのに最も広く用いられている方法は，ス リット光を用いた光切断法である.

本稿では, 光切断法の原理とこれを応用した 3 次元 視覚センサ,およびそれらを用いた 3 次元計測と検査 システムについて述べる.

\section{2. 光切断法の原理}

光切断法は, 図 1 に示すよらにスリット状の光を対 象物体に投射してその反射光を受光素子で検出する方 法である.スリット光はスポット光を円筒レンズでス リット状にして得るが，スポット光を 1 次元走査して も得ることができる. スリット光を用いた光切断法は 一度に 1 スリット（光切断線）分の 3 次元座標が得ら れることから，現時点では最も実用的な方法である.

図 2 は, この方法に用いられている三角測量法の原

\footnotetext{
* 原稿受付 平成 2 年 6 月 6 日

** 正 会 員 (株)豊田中央研究所 (愛知県愛知郡長久手町大 字長淡字横道)
}

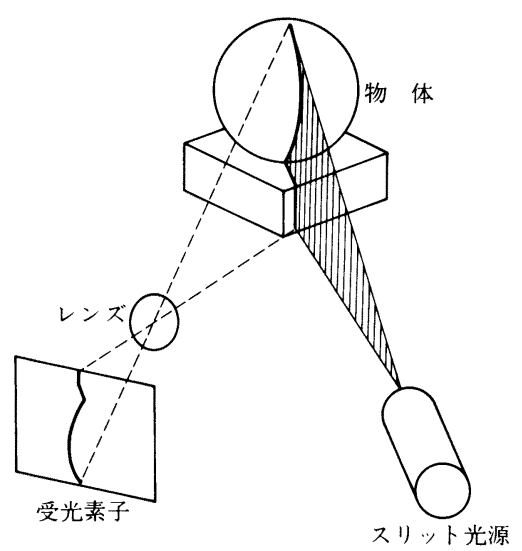

図1 光切断法

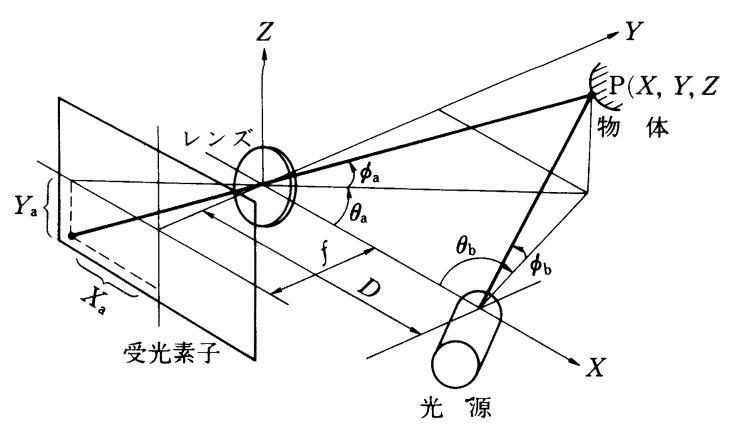

$X=D \cos \theta_{\mathrm{a}} \sin \theta_{\mathrm{b}} / \sin \left(\theta_{\mathrm{a}}+\theta_{\mathrm{b}}\right)$

$Y=D \sin \theta_{\mathrm{a}} \sin \theta_{\mathrm{b}} / \sin \left(\theta_{\mathrm{a}}+\theta_{\mathrm{b}}\right)$

$Z=D \tan \phi_{\mathrm{a}} / \sin \theta_{\mathrm{a}}$

たたし， $\theta_{\mathrm{a}}=\tan ^{-1}\left(f / X_{\mathrm{a}}\right)$ $\phi_{\mathrm{a}}=\tan ^{-1}\left(Y_{\mathrm{a}} \cos \theta_{\mathrm{a}} / X_{\mathrm{a}}\right)$

ここで, $D:$ 基線長, $f:$ レンズの焦点距離, $X_{\mathrm{a}}, Y_{\mathrm{a}}:$ 受 光素子上のスポット光像の位置

図 2 三角測量法の原理 


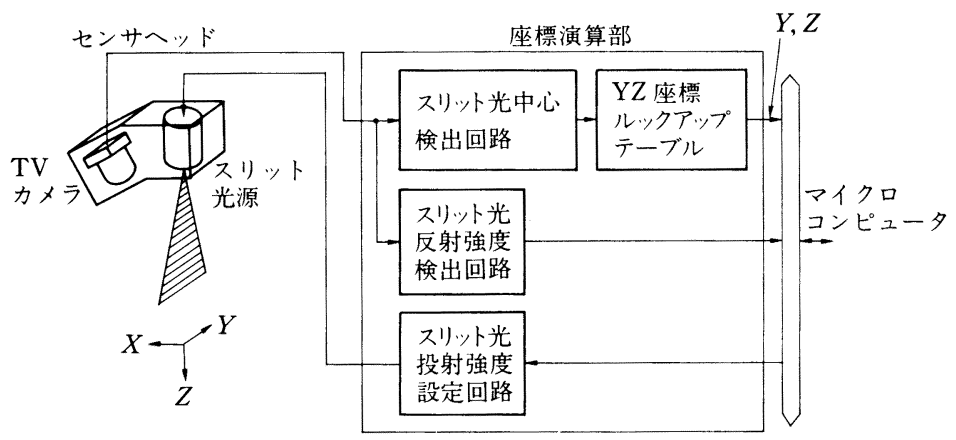

図 33 次元視覚センサの構成

表 13 次元視覚センサの性能

\begin{tabular}{l|l}
\hline 動作距離 & $70 \mathrm{~mm}(Z)$ \\
測定範囲 & $30 \mathrm{~mm}(Y) \times \pm 10 \mathrm{~mm}(Z)$ \\
測定点数 & 484 点 \\
測定精度 & $\pm 0.1 \mathrm{~mm}(Y, Z)$ \\
寸 法 & $150 \mathrm{~mm}(W) \times 110 \mathrm{~mm}(H) \times 55 \mathrm{~mm}(D)$ \\
重 量 & $720 \mathrm{~g}$ \\
\hline
\end{tabular}

理を示したものである.レンズをピンホールで近似す ると, 点 $\mathrm{P}$ の 3 次元座標 $(X, Y, Z)$ は, 図中の式の ように受光素子上のスポット光像の位置より求めるこ とができる.

\section{3 次元視覚センサ}

光切断法を用いた 3 次元視覚センサを生産工程で使 用するためには，スリット光像の高速・高精度検出と センサヘッドの小型化が必要である.

図 3 は, このような目的のために開発された光切断 法を用いた 3 次元視覚センサ ${ }^{11}$ の構成である. このセ ンサは，センサヘッドと座標演算部で構成されてい る. 高速に 3 次元座標を検出するために，座標演算は すべてハードウェアによりパイプライン処理され，ま た高精度化のために光切断線の重心位置が求められて いる. また，対象物体の表面性状の影響を受け難くす るために，スリット光の対象物体からの反躬強度に応 じて投射する光強度が制御される.

表 1 にこの 3 次元視覚センサの性能を示す. 測 定範囲は, 動作距離 $70 \mathrm{~mm}$ の位置で $30 \mathrm{~mm}$ $(Y) \times \pm 10 \mathrm{~mm}(Z)$ である. 測定精度は \pm 0.1 $\mathrm{mm}$, 測定時間は 1 スリット分の 484 点の演算に $33.3 \mathrm{~ms}$ である.

図 4 は, スポット光を 1 次元走查して得たス リット光の 3 次元視覚センサである. このセンサ は2 次元同期走査型 2 で，光源に $\mathrm{He}-\mathrm{Ne} レ$ ーザ が, 受光素子に 1024 素子のリニアアレイが, 走 査するのにポリゴンミラーが用いられている. 測
定範囲は $50 \mathrm{~cm}(X) \times 50 \mathrm{~cm}(Y)$, 測定精度は $\pm 0.25 \mathrm{~mm}$ である.

その他，スリット光を交差させた 十字スリット光の 3 次元視覚セン サ3) 開発されている.

\section{3 次元計測と検査システム}

\section{1 自動車部品の形状計測シス テム}

自動車の検査や試作の工程では, 部品やその型の形状計測が頻繁に行 われる. その形状計測には, 完成部品が設計通りに仕 上げられているのかの形状検査と試作品の形状データ の測定がある.

図 5 は，自動車部品の仕上がり形状を検査するシス テム4) の構成である. このシステムは, 前述の 3 次元 視覚センサ1), 部品を移動するためのパルスステー ジ，そのコントローラ拈よびパソコン等で構成されて いる，パソコンでは，ステージの位置決め， 3 次元座

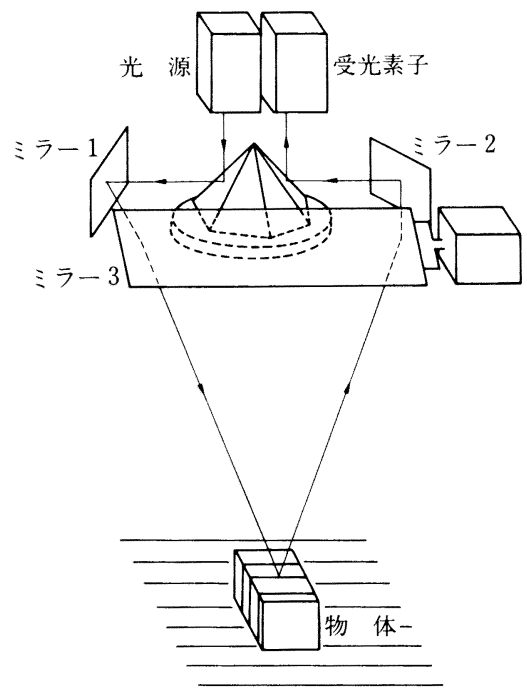

図 42 次元同期走查 3 次元視覚センサ

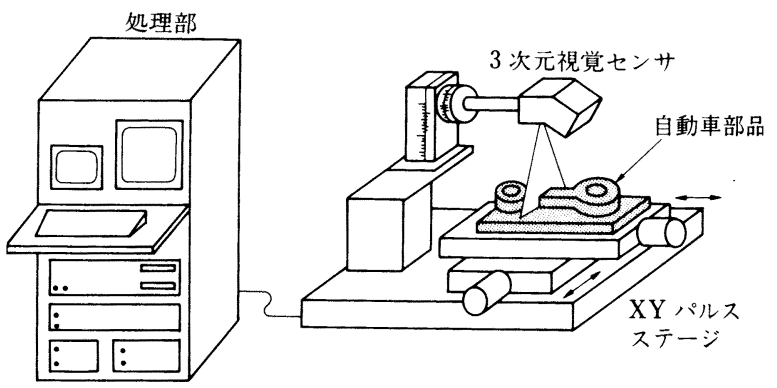

図 5 自動車部品形状計測システムの構成 


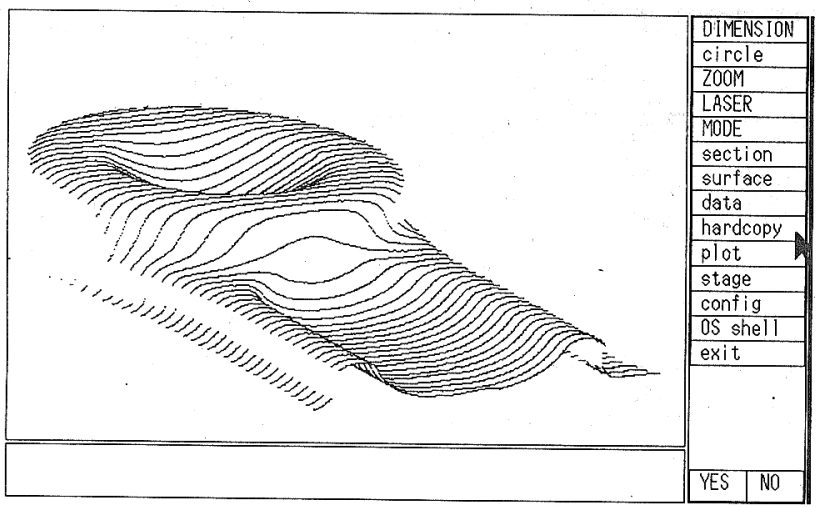

図 6 形状測定の一例

標の検出と演算処理，およびその結果のグラフ表示が 行われる。

図 6 は，このシステムで自動車部品を測定したとき

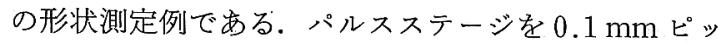
チで送り， $50 \mathrm{~mm}(X) \times 30 \mathrm{~mm}(Y)$ の範囲を100ス リット（48400 点）で測定したときの図である. 測定 時間は，33.3sである.このうち，3 次元座標の検出 に $3.3 \mathrm{~s}$, ステージの移動とグラフ表示に $30 \mathrm{~s}$ 要して いる.

このシステムは，このような全体形状測定の外に断 面形状測定の機能も有している，測定対象物体の表面 性状により，3次元視覚センサのスリット光の投射強 度の自動設定も行える。このシステムの測定範囲は $200 \mathrm{~mm}(X) \times 200 \mathrm{~mm}(Y) \times 100 \mathrm{~mm}(Z)$ で，総 合測 定精度は土0.15 mm である.

図 7 は，試作品の形状データ測定のために筆者らが 開発したシステムである. 非接触で高速に測定するた めに片持ち式の 3 次元自動測定機の先端に 3 次元視覚 センサ1)が装着されている。

全体形状測定や断面形状測定に加壳て, 端点や交点 の測定機能孔持っている. システムとしての性能は， $500 \mathrm{~mm}(X) \times 800 \mathrm{~mm}(Y) \times 600 \mathrm{~mm}(Z)$ の範囲を総 合精度 $\pm 0.25 \mathrm{~mm}$ で測定する。

\section{2 船舶用プロペラの形状計測システム}

船舶用プロペラは，鋳造・切削・研磨の各工程を経 て製作され，その後工程で代表部位が計測される：し かし，製品の最終検査では全体形状の測定は欠かせな い.

図 8 は, 直径 $14 \mathrm{ft}$ の船舶用プロペラの形状計测用 に開発されたシステム皃である。このシステムは，直 交ロボット，3 次元視覚センサ，プロペラ支持台等で 構成され，ロボットと 3 次元視覚センサの制御や測定 データの処理はパソコンで行われる. 3 次元視覚セン

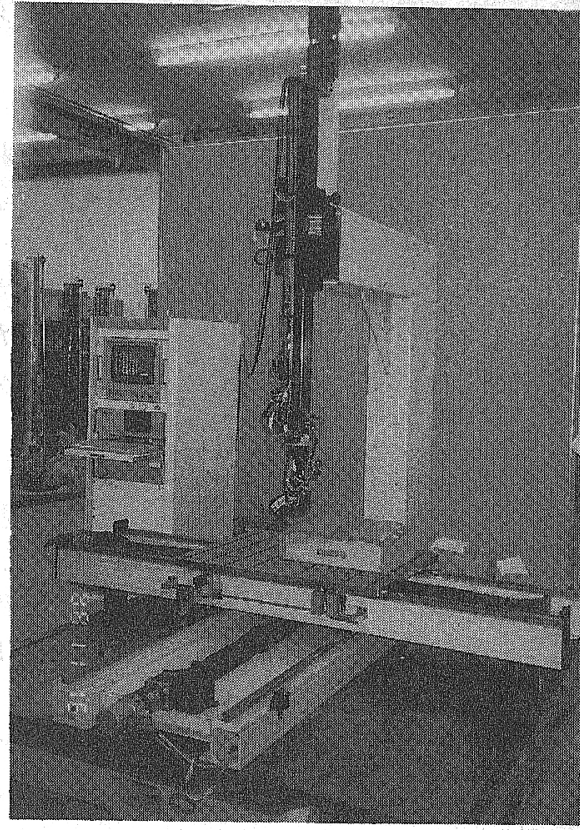

图 7 自動車部品の形状計測用 3 次元自動測定機

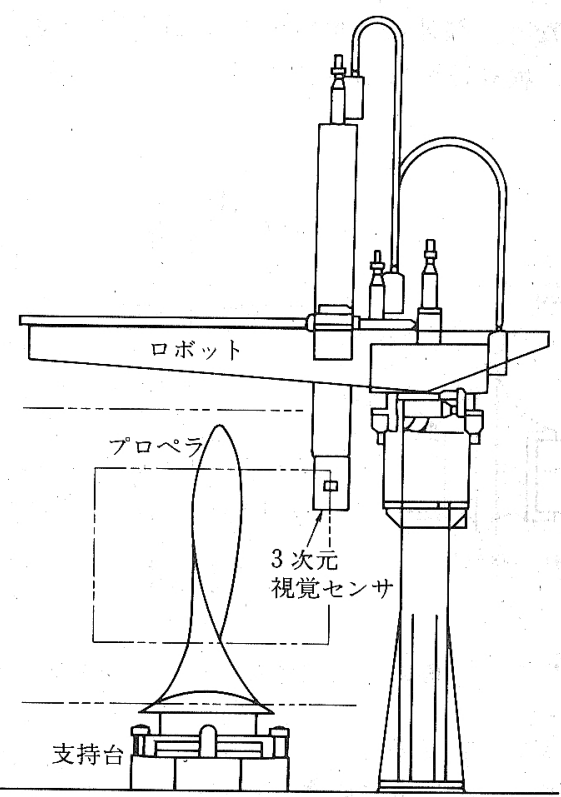

図 8 船舶用プロペラの形状計測システム

サとしては 2 次元同期走査型のセンサ ${ }^{2)}$ が用いられて いる.

従来は接触式のセンサが使用されていたが，この非 接触式の 3 次元視覚センサを用いることにより従来 1 日に200点しか测定できなかったものが土0.25 mm の測定精度で $1 \mathrm{~h}$ で 20 万点が測定できるようになり， 
測定の信頼性と省力化が大幅に改良されたと報 告されている.

同種のプロペラ形状計測システム ${ }^{6)}$ やタービ ンブレードの形状計測システム7) も開発されて いる.

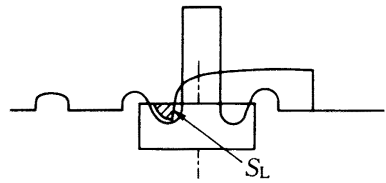

はんだ不足

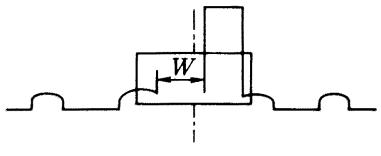

はんだなし

\section{3 はんだ付検査システム}

はんだ付部の欠陥を検査するのに，はんだ付 部の外観形状で検査する方法がある.はんんだ付 部欠陥は，大別すると図 9 に示す 4 種類に分類 される.

図 10 に，この検査システム ${ }^{8)}$ の概要を示す. スリット光をはんだ付部の垂直上方から投射

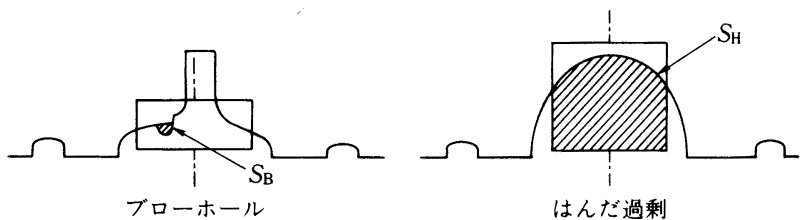

図 11 はんだ付部欠陥の判定

し，その反射光を TVカメラで検出する．検

出されたスリット光像は濃淡画像として得られるの

で，これから光切断線だけを抽出して，波形解析を行

い, その後欠陷の判定が行われる.

欠陥の判定は, 図 11 の設定領域内の 4 つの特徵量 （面積 $S_{\mathrm{L}}, S_{\mathrm{B}}, S_{\mathrm{H}}$ と断線長さ $W$ ）を求めることによっ て行われる.

このシステムの性能評価実験では, 欠陥の見落とし はなく，前述の 4 種類の欠陌が安定に検出されてい る. 検査速度は 10 点/ $\mathrm{s}$ である.

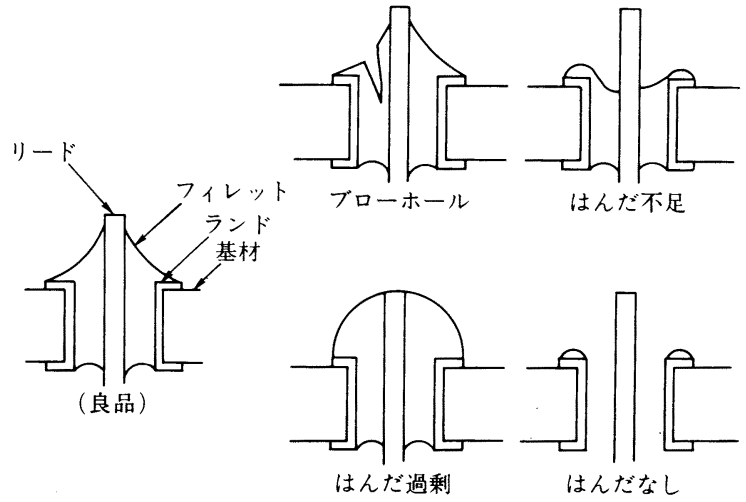

図 9 はんだ付部の欠陷（代表 4 種類）

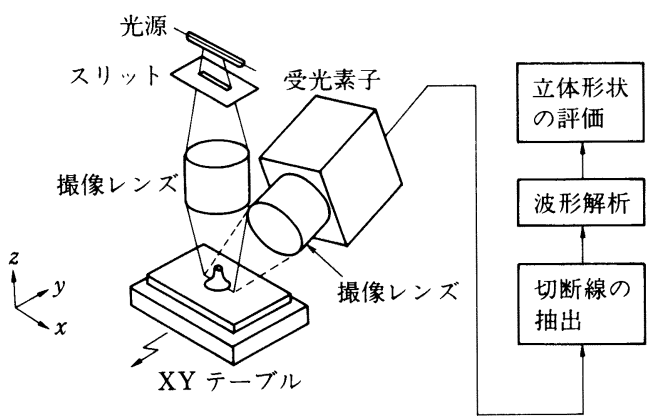

5. ま と め

光切断法を用いた 3 次元計測の方法と検査システム の開発例について述べた.このような 3 次元検査の自 動化への要望は, 今後もますます増加の傾向にある.

生産工程に打ける 3 次元計測・検査の自動化は, 高 速・高精度かつ検出安定度の高い 3 次元視覚センサの 開発に尽きる. 現時点では死角の問題や対象物体の色 と表面性状の制約を受ける問題はあるが，スポット光 方式や光切断方式の 3 次元視覚センサが最も実用性が 高く，ここしばらくはこの方式が主流になろう.

今後, 上り高度な 3 次元計測・検査システムの実現 には, 処理手法の高度化やニューロ, ファジィなどの 新しい技法の活用が必要である.

\section{参 考 文 献}

1）小関 修, 中野倫明，山本 新：画像処理技術を用いた 非接触寸法測定 プローブ, 昭 62 信学総全大, S 12-3 (1987) 224.

2) M. Rioux : Laser Range Finder Based on Synchro-nized Scanners, Appl. Opt., 23, 21, (1984) 3837.

3）例之ば, 岡田拓史, 秦 清治, 高木裕治：立体形状の高 速認識方式，精密工学会誌，52，6（1986） 82.

4）桶口和則, 小関 修, 塚田敏彦, 山本 新: 形状計測用 3 次元視覚センサ, 1989 年度精密工学会春季大会学術講演 会講演論文集（1989）949.

5) F. R. Livingstone et al. : Application of 3-D Vision to Measurement of Marine Propellers, Proc. Vision '87, (1987) 10.

6) N. Okina, K. Minowa \& K. Okamoto: ThreeDimensional Measurement System by Servomechanism, 11th ISIR, (1981) 437.

7）押田良忠, 黒梅弘焗, 梅原昇, 川田陽一：三次元自由 曲面形状のレーザ自動計測装置の開発, 第 20 回 SICE 学 術講演会予稿集 (1981) 205.

8）中川泰夫, 牧平担, 秋山伸幸, 蔵部弘敏: 光切断法に よるプリント板はんだ付部の自動外観検査, 第 19 回 SICE 学術講演会予稿集（1980） 163.

図 10 はんだ付部外観検査 